\title{
Proof-of-concept study on improved efficacy of rHuEPO administered as a long-term infusion in rats
}

\author{
Damian Szczesny ${ }^{1} \cdot$ Katarzyna Mołoniewicz $^{1} \cdot$ Michał J. Markuszewski ${ }^{1} \cdot$ Paweł Wiczling $^{1}$ (i)
}

Received: 14 April 2020 / Revised: 24 July 2020 / Accepted: 27 July 2020 / Published online: 3 August 2020

(c) The Author(s) 2020

\begin{abstract}
Background Human recombinant erythropoietin (rHuEPO) is often used in the treatment of diseases associated with a decreased production of red blood cells (RBC), such as chronic renal failure. rHuEPO is typically administered as an intravenous or subcutaneous (SC) injection every few days. The low minimum effective concentration (MEC) of rHuEPO, compared to the concentrations observed after standard doses, suggests that a low dose of the drug administered as a long-term infusion should be efficacious. This study aimed to compare the efficacy observed after a single subcutaneous administration of rHuEPO with that observed after a long-term infusion of rHuEPO via implanted osmotic pumps at a similar or lower dose. Materials and methods In this study three rats received rHuEPO as a single SC injection at a dose of $1350 \mathrm{IU} / \mathrm{kg}$, nine via osmotic pumps at a rate of $0.25,0.5$ and $1 \mathrm{IU} / \mathrm{kg}$ and at a total dose of $333 \mathrm{IU} / \mathrm{kg}, 667 \mathrm{IU} / \mathrm{kg}, 1333 \mathrm{IU} / \mathrm{kg}$. Three rats served as a control group. The erythropoietin concentrations, RBC count and hemoglobin were measured.

Results An increase in RBC count and hemoglobin was observed after SC infusion of rHuEPO. The baseline corrected area under the effect curve for hemoglobin and RBC count was more than 10-times higher for the SC infusion than for a single SC administration with a comparable dose.

Conclusions This study demonstrates that administration of rHuEPO as a long-term infusion at a rate ensuring MEC allows to achieve a high efficacy of therapy using relatively small doses of the drug.
\end{abstract}

Keywords Erythropoietin · Osmotic pumps · Target-mediated drug disposition · Minimal effective concentration ·

Subcutaneous infusion

\section{Introduction}

Erythropoietin (EPO) is a glycoprotein involved in maintaining sufficient red blood cells (RBC) production [1]. In adult humans, EPO is produced mainly by the renal cortex, which contributes to $\sim 90 \%$ of the blood level of this hormone. Other organs producing EPO include liver, spleen, lungs, testis, brain, and erythroid progenitor cells. In a healthy human, the blood concentration of EPO is $10 \mathrm{pM}$ $(<5-25 \mathrm{IU} / \mathrm{l})$ [2]. It is similar to the baseline value reported for rats (5.4 IU/l) [3]. Erythropoietin is a main regulator of erythropoiesis, a process in which new erythrocytes origins from pluripotent stem cells in the bone marrow. In humans and other mammals, erythropoiesis is a slow process in

Paweł Wiczling

wiczling@gumed.edu.pl

1 Department of Biopharmacy and Pharmacodynamics, Medical University of Gdańsk, 80-416 Gdańsk, Poland which old RBCs are replaced with young reticulocytes. In some pathologic conditions, like hemorrhage or severe hemolysis, the rate of reticulocyte production may increase even eight times and an increase in EPO concentration might be 1000-fold [2, 4].

Erythropoietin binds to the specific erythroid progenitor cell surface receptor (EPO-R) to regulate bone marrow erythroid cell proliferation, differentiation, and survival. Binding to EPO-R expressed on the erythroid progenitor cells in the bone marrow has been reported as an important pathway of EPO elimination [5, 6].

Recombinant human erythropoietin ( $\mathrm{rHuEPO})$ is a biotechnologically derived drug widely used in the treatment of different types of anemia, like anemia associated with chronic kidney disease, in HIV-infected or cancer patients. rHuEPO is often administered as a SC or IV injection, up to three times a week [7]. It was demonstrated, that higher pharmacological response might be achieved after SC administration and divided doses [8]. 
This observation led to the assumption, that pharmacological response depends on the time when EPO concentration exceeds a certain level instead of peak concentration. This concentration was called "critical" by Besarab et al. [8], later renamed into "minimum effective concentration". According to this hypothesis, prolonged administration of EPO keeps its concentration above minimum effective concentration (MEC) and can produce an equal or higher pharmacological effect, even when the total dose of EPO is lower than after bolus injection [9]. The MEC value in humans ranges from 60 to $20 \mathrm{mIU} / \mathrm{ml}$ and is close to the blood concentration of EPO [9]. The relatively low value of MEC for rHuEPO has an interesting implication for rHuEPO dosing, especially if given as a constant infusion. As an example, to achieve rHuEPO concentration in rats four-fold higher than the baseline EPO concentration $(\mathrm{Ct}=4 \times 5.4 \mathrm{IU} / \mathrm{l})$, rHuEPO needs to be administered at a fairly small rate of $25.5 \times 21.6 / 1000=0.551 \mathrm{IU} / \mathrm{h} /$ $\mathrm{kg}$. In this calculation an apparent rHuEPO clearance of $\mathrm{CL} / F=25.50 \mathrm{ml} / \mathrm{h} / \mathrm{kg}$ was assumed [10]. Consequently, a rHuEPO dose of $1350 \mathrm{IU} / \mathrm{kg}$ allows one to perform an infusion for about 102 days (1350/0.551). Since under the MEC hypothesis, EPO is effective for concentrations exceeding baseline concentrations, this calculation shows that large efficacy can be achieved by administering a single rHuEPO dose over a long time.

Based on the above-mentioned premises, this study was developed to compare the pharmacological effect of EPO observed after a single SC injection at a $1350 \mathrm{IU} / \mathrm{kg}$ dose and a long-term SC infusion at a similar or lower dose. For that purpose, pharmacokinetic and pharmacodynamic (PK/ $\mathrm{PD})$ of $\mathrm{rHuEPO}$ during this infusion via implanted osmotic pumps was determined.

\section{Materials and methods}

\section{Animals}

Animal care and handling were carried out according to the protocol approved by the Local Ethical Committee for Animal Research at the Medical University of Gdańsk. The male Wistar rats were obtained from Tri-city's Academic Animal Experiment Centre, Gdańsk, Poland. All animals were accommodated in the laboratory for at least 2 weeks before the start of the study. They entered the study when they were 6 weeks old and weighted $\sim 300 \mathrm{~g}$. Animals were fed with standard chow (Labofeed H Standard, Diet Manufacturer Morawski, Poland) contains $150 \mathrm{mg}$ of iron per kilogram and water ad libitum and were housed in a room with 12/12-h light/dark cycle.

\section{Experimental procedures}

In total 15 rats were used in this experiment. Animals were divided into five groups $(n=3)$. Erythropoietin (Epogen, $2000 \mathrm{IU} / \mathrm{ml}$, Amgen, Thousand Oaks, USA) was administered by two routes: single bolus SC injection (1350 IU/ $\mathrm{kg}$, solution in $0.9 \%$ sodium chloride) in one group, and by continuous SC infusion via osmotic pumps (Alzet, model 2002, DURECT Corporation, Cupertino, USA), with following nominal rates of infusion: 1.0, 0.5 and $0.25 \mathrm{IU} / \mathrm{h}$, for 14 days. Pumps were filled with rHuEPO solution in $0.9 \%$ sodium chloride at a total dose of $1333 \mathrm{IU} / \mathrm{kg}, 667 \mathrm{IU} /$ $\mathrm{kg}$, and $333 \mathrm{IU} / \mathrm{kg}$. One group received a $0.9 \%$ solution of sodium chloride only and served as a control. The rates were determined based on the simulation of a pharmacokinetic model published by Woo et al. [10] to ensure the concentrations of rHuEPO 2-, 4-, and 8-times higher from the endogenous EPO concentrations. The latter was assumed to equal $5.4 \mathrm{mIU} / \mathrm{ml}$ in rats [3].

\section{Osmotic pumps implantation}

Osmotic pumps were filled with a solution of rHuEPO after proper dilution in $0.9 \%$ sodium chloride. $2000 \mathrm{IU} / \mathrm{ml}$ primary solution of erythropoietin was diluted with $0.9 \%$ sodium chloride at a ratio of 1:1, 1:2, and 1:4. Each dilution was used for filling three osmotic pumps at a volume of $200 \mu$ l. Pumps were then implanted subcutaneously on the middle-back of an animal in sterile conditions under the anesthesia. As an anesthetic agent, 1-3\% isoflurane (Forane, Abott, Kent, UK) in breathed air was used. Wounds were closed with wound clips and clips were removed after 1 week. There were no signs of infection or inflammation in the site of pump implantation.

\section{Pharmacokinetic and pharmacodynamic study}

To determine pharmacokinetic and pharmacodynamic properties of rHuEPO, $100 \mu \mathrm{l}$ of blood was taken before osmotic pump implantation or SC administration of rHuEPO and then after 5, 24, 48 and $72 \mathrm{~h}$ (SC injection group only) and 5, $10,15,17,19,22,29$ days (each group). For red blood cells and hemoglobin quantification, $50 \mu \mathrm{l}$ of blood was taken at baseline and 2, 5, 6, 8, 10, 13, 15, 17, 20, 22, 24, 27, 29, 31, $34,41,48,55$, and 62 day (each group) after the beginning of the experiment. Coagulation of fresh whole blood was prevented using 1\% EDTA in amounts not exceeding $10 \%$ of the blood sample by volume.

The blood was centrifuged (3500 rpm, $10 \mathrm{~min}$, room temperature), serum was separated and frozen in $-80{ }^{\circ} \mathrm{C}$ until erythropoietin level was determined by Quantikine 
IVD ELISA (Human EPO Immunoassay, R\&D System Inc., Minneapolis, USA) following manufacturer instructions. Concentrations were determined based on the standard curve, linear from 2.5 to $200 \mathrm{mIU} / \mathrm{ml}$. The detection limit was $2.5 \mathrm{mIU} / \mathrm{ml}$. Samples with a concentration higher than $200 \mathrm{mIU} / \mathrm{ml}$ were diluted with the solvent provided by the manufacturer of assay kit. The assay did not cross-react with endogenous EPO. The conversion from IU/l to $\mathrm{pM}$ was made assuming $7.7 \mathrm{mg}$ of rHuEPO is equivalent to $1000 \mathrm{IU}$ and the molecular weight of rHuEPO of $30.4 \mathrm{kD}$ [11].

Hematological analysis was done with use of ABC VET hematological analyzer (Horiba Medical Diagnostics Instruments and Systems, Montpellier, France) immediately after blood sampling.

\section{Statistical analysis}

The calculation of AUC for noncompartmental analysis has been done by the trapezoidal method with extrapolation to infinity based on the last two observed points. The comparison of the pharmacological effect for various methods of administration and different doses of rHuEPO was based on maximal observed $\mathrm{RBC}$ and $\mathrm{Hb}$ values, and the area under the effect curve (AUCE). The latter allows the comparison of net effect of drug [12]. AUCE was calculated by the trapezoidal integration over the time of measurements.

The difference between the control and rHuEPO treated rats was tested using Kruskal-Wallis test (a nonparametric version of one-way ANOVA) with Dunn-Bonferroni post hoc method for multiple comparisons. $p$ value $<0.05$ was accepted as significant. Statistical analysis was performed in $\mathrm{R}$ environment ( $\mathrm{R}$ Core Team 2019) using dunn.test package version 1.3.5.

\section{Results}

In this study rats received rHuEPO as a single subcutaneous injection and as a subcutaneous infusion at three different rates of $0.25 \mathrm{IU} / \mathrm{h}, 0.5 \mathrm{IU} / \mathrm{h}, 1 \mathrm{IU} / \mathrm{h}$. Implantation of the osmotic mini-pumps under the skin fold located on the neck of the animal was a relatively simple procedure without any complications. The wound healed quickly and the pump itself did not interfere with the normal functioning of the animal.

The rHuEPO serum concentrations are shown in Fig. 1. When using the osmotic pump in vivo concentrations increased and sustained steady state values from day 5 to day 22. The basic PK parameters were calculated by noncompartmental analysis and are summarized in the Table 1. For SC infusion groups, steady-state concentrations were 7.03, 10.3 and $23.1 \mathrm{mIU} / \mathrm{ml}$ after 333, 667 and $1333 \mathrm{IU} / \mathrm{kg}$ dose of rHuEPO. These values are much lower than concentrations

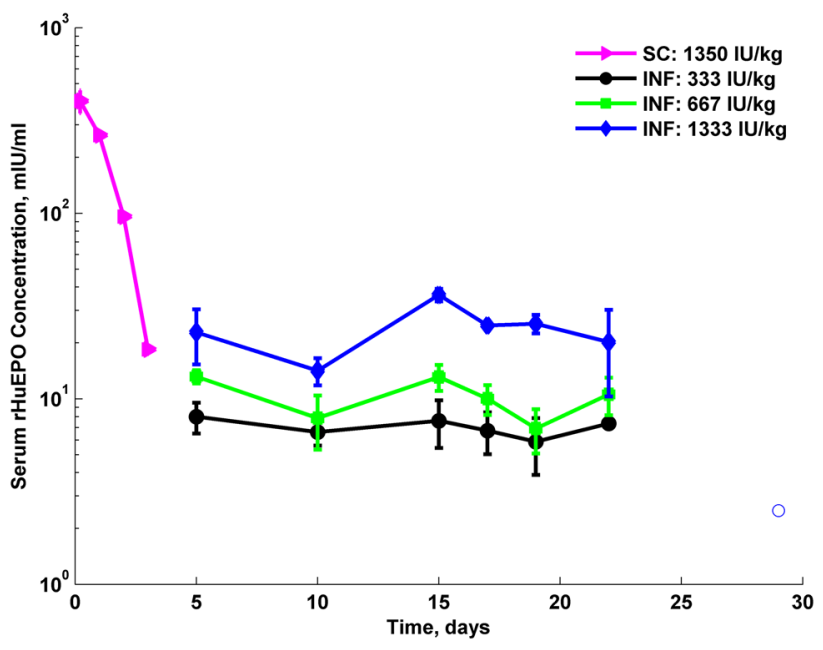

Fig. 1 Time course of rHuEPO serum concentrations after single SC injection of $1350 \mathrm{IU} / \mathrm{kg}$, and three subcutaneous infusions at nominal rates $0.25,0.5$ and $1 \mathrm{IU} / \mathrm{h}$. The mean observed data are represented as solid symbols with SD error bars. The open symbol denotes concentration below lower limit of quantification of the assay

Table 1 The basic PK parameters and their standard deviations obtained after SC infusion and SC injection of rHuEPO in rats

\begin{tabular}{lllll}
\hline Group, IU/kg & $C_{\mathrm{ss}}, \mathrm{mIU} / \mathrm{ml}$ & $R_{0}, \mathrm{IU} / \mathrm{h}$ & $\mathrm{CL} / F, \mathrm{ml} / \mathrm{h}$ & $\begin{array}{l}\mathrm{CL} / F / \mathrm{BW}, \mathrm{ml} / \mathrm{h} / \\
\mathrm{kg}\end{array}$ \\
\hline INF: 333 & $7.03(1.3)$ & 0.25 & $36.3(6.7)$ & $121.2(22.3)$ \\
INF: 667 & $10.3(1.1)$ & 0.5 & $49.0(5.4)$ & $163.5(17.8)$ \\
INF: 1333 & $23.1(2.7)$ & 1 & $43.7(5.0)$ & $145.6(16.8)$ \\
SC: 1350 & - & - & $29.7(3.7)$ & $99.1(12.3)$
\end{tabular}

The apparent clearance were calculated as a ratio of nominal rate $\left(R_{0}\right)$ and steady-state concentrations $\left(C_{\mathrm{ss}}\right)$, for single injection as a dose over AUC. Data are presented as mean (SD)

observed within first two days after single SC injection of rHuEPO. Apparent clearances, calculated as a ratio of a nominal rate by steady-state concentration (for infusion groups) or dose over AUC (SC injection) were 36.3, 49.0, $43.7 \mathrm{ml} / \mathrm{h}$ for infusion with rate of $0.25,0.5$ and $1.0 \mathrm{IU} / \mathrm{h}$, respectively, and $29.7 \mathrm{ml} / \mathrm{h}$ for rats injected with $\mathrm{rHuEPO}$.

To investigate pharmacodynamics of rHuEPO after SC infusion and injection, red blood cells count (RBC) and hemoglobin concentration $(\mathrm{Hb})$ were measured. Changes in $\mathrm{RBC}$ and $\mathrm{Hb}$ in rats are shown in Fig. 2. The results are summarized in Table 2.

We observed a dose-dependent increase of RBC count and hemoglobin level upon mini-pump implantation. Rats administered with rHuEPO at a rate of $0.25 \mathrm{IU} / \mathrm{h}$ showed an increase in $\mathrm{RBC}$ and $\mathrm{Hb}$ to a maximum of $10.2 \times 10^{6}$ cells/ $\mu \mathrm{l}$ and $18.7 \mathrm{~g} / \mathrm{dl}$, respectively. The $0.5 \mathrm{IU} / \mathrm{h}$ group reached maximal $\mathrm{RBC}$ and $\mathrm{Hb}$ responses of $10.6 \times 10^{6} \mathrm{cells} / \mu \mathrm{l}$ and $18.9 \mathrm{~g} / \mathrm{dl}$, and the $1 \mathrm{IU} / \mathrm{h}$ group reached maximal RBC and 
Fig. 2 Time course profiles of mean hemoglobin concentrations and RBC count for control, single SC injection of $1350 \mathrm{IU} / \mathrm{kg}$, and three subcutaneous infusions at nominal rates of $0.25,0.5$ and $1 \mathrm{IU} / \mathrm{h}$. The mean observed data are represented as solid points with SD error bars
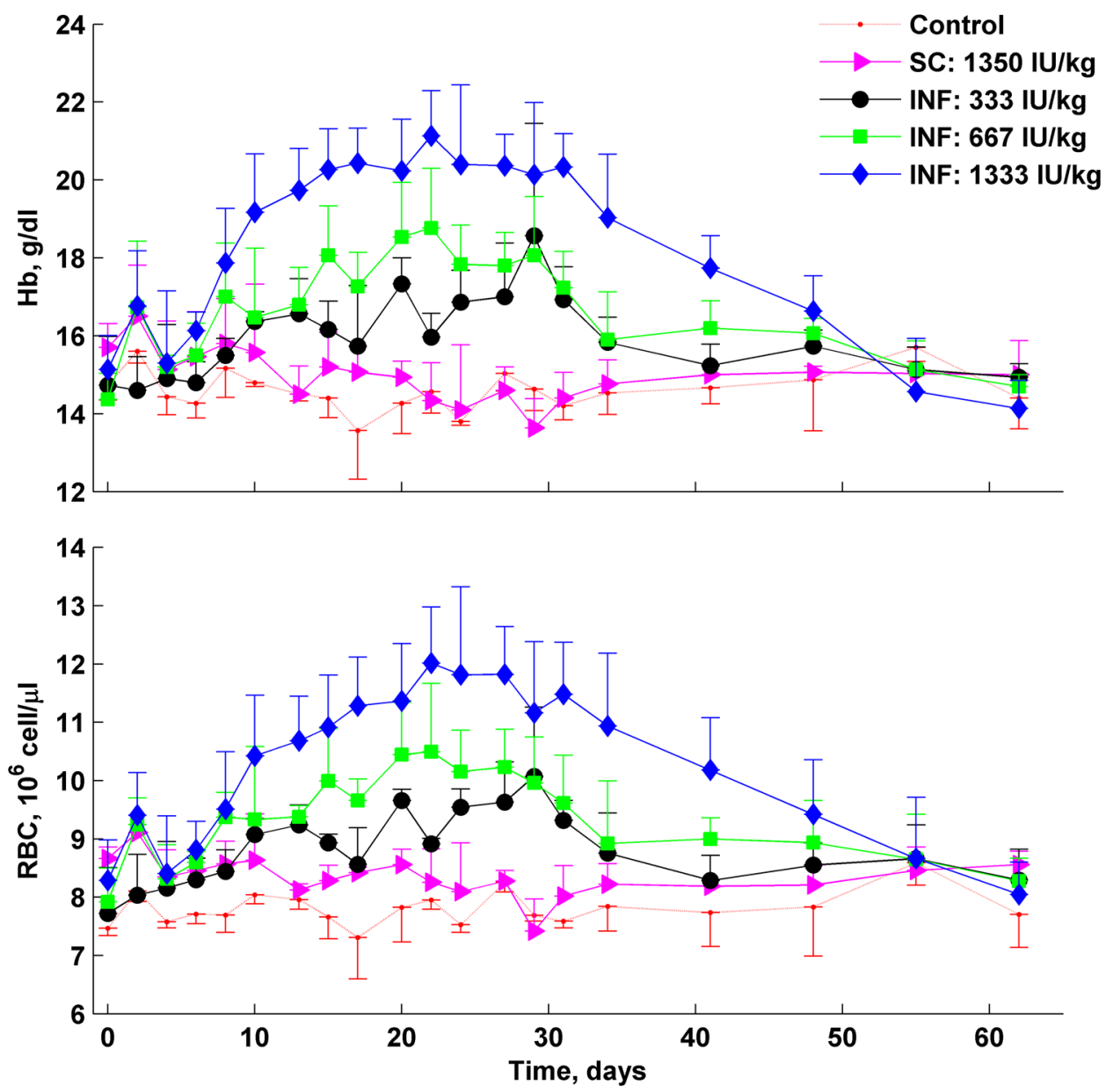

Table 2 The area under the effect curve (AUCE) and maximal value for $\mathrm{Hb}$ and $\mathrm{RBC}$ in control and rHuEPO treated rats

\begin{tabular}{|c|c|c|c|c|}
\hline Group & AUEC for RBC, $10^{6}$ cells $/ \mu \mathrm{l} \cdot$ day & AUEC for $\mathrm{Hb}, \mathrm{g} / \mathrm{dl} \cdot \mathrm{day}$ & Max RBC, $10^{6}$ cells $/ \mu \mathrm{l}$ & $\mathrm{Max} \mathrm{Hb}, \mathrm{g} / \mathrm{dl}$ \\
\hline Overall test $(n=15)$ & $\begin{array}{l}\text { Chi-sq }=12.43, d f=4 \\
*(p=0.01)\end{array}$ & $\begin{array}{l}\text { Chi-sq }=12.1, d f=4 \\
*(p=0.02)\end{array}$ & $\begin{array}{l}\text { Chi-sq }=10.9, d f=4 \\
*(p=0.03)\end{array}$ & $\begin{array}{l}\text { Chi-sq }=10.4, d f=4 \\
*(p=0.03)\end{array}$ \\
\hline Control $(n=3)$ & $\begin{array}{l}488( \pm 20) \\
497(473-500)\end{array}$ & $\begin{array}{l}911( \pm 18) \\
920.6(898-921)\end{array}$ & $\begin{array}{l}8.6( \pm 0.4) \\
8.7(8.3-8.8)\end{array}$ & $\begin{array}{l}16.0( \pm 0.4) \\
15.9(15.9-16)\end{array}$ \\
\hline INF: $333 \mathrm{IU} / \mathrm{kg}(n=3)$ & $\begin{array}{l}543( \pm 17) \\
539(532-556) \\
(p=0.34)\end{array}$ & $\begin{array}{l}981( \pm 16) \\
984(960-993) \\
(p=0.60)\end{array}$ & $\begin{array}{l}10.2( \pm 1.0) \\
9.8(9.5-11.0) \\
(p=0.50)\end{array}$ & $\begin{array}{l}18.7( \pm 2.8) \\
17.2(17.0-20.7) \\
(p=0.41)\end{array}$ \\
\hline $\begin{array}{l}\text { INF: } 667 \mathrm{IU} / \mathrm{kg} \\
(n=3)\end{array}$ & $\begin{array}{l}571.6( \pm 37) \\
569(544-600) \\
(p=0.07)\end{array}$ & $\begin{array}{l}1021( \pm 40) \\
1020(991-1051) \\
(p=0.18)\end{array}$ & $\begin{array}{l}10.6( \pm 1.0) \\
10.3(9.9-11.4) \\
(p=0.11)\end{array}$ & $\begin{array}{l}18.9( \pm 1.5) \\
18.6(18.0-20.0) \\
(p=0.14)\end{array}$ \\
\hline INF: $1333 \mathrm{IU} / \mathrm{kg}(n=3)$ & $\begin{array}{l}627( \pm 56) \\
650(584-663) \\
*(p=0.0096)\end{array}$ & $\begin{array}{l}1109( \pm 67) \\
1135(1059-1152) \\
*(p=0.017)\end{array}$ & $\begin{array}{l}12.2( \pm 1.0) \\
12.8(11.5-12.8) \\
*(p=0.0096)\end{array}$ & $\begin{array}{l}21.3( \pm 1.2) \\
21.9(20.4-22.0) \\
*(p=0.011)\end{array}$ \\
\hline SC: $1350 \mathrm{IU} / \mathrm{kg}(n=3)$ & $\begin{array}{l}516( \pm 5) \\
515(512-520) \\
(p=1.0)\end{array}$ & $\begin{array}{l}928( \pm 24) \\
921(911-946) \\
(p=1.0)\end{array}$ & $\begin{array}{l}9.56( \pm 0.3) \\
9.54(9.34-9.77) \\
(p=1.0)\end{array}$ & $\begin{array}{l}17.2( \pm 0.7) \\
17.2(16.8-17.6) \\
(p=1.0)\end{array}$ \\
\hline
\end{tabular}

Data are presented as mean $( \pm \mathrm{SD})$ and medians (quartiles, 25th-75th percentile). The Kruskal-Wallis rank sum test with Dunn-Bonferroni post hoc method was used to compare groups. Asterisk denotes statistically significant increase over control values 
$\mathrm{Hb}$ responses of $12.2 \times 10^{6}$ cells $/ \mu \mathrm{l}$ and $21.3 \mathrm{~g} / \mathrm{dl}$. The RBC and $\mathrm{Hb}$ increased to about 30 days after pump implantation. Between day 30 and day 60 a linear decline of RBC and $\mathrm{Hb}$ toward the baseline was observed due to the discontinuation of rHuEPO administration.

The maximum value for $\mathrm{RBC}$ and $\mathrm{Hb}$ responses after a single SC injection was recorded $48 \mathrm{~h}$ after administration of rHuEPO and equaled to $9.56 \times 10^{6}$ cells $/ \mu \mathrm{l}$ and $17.2 \mathrm{~g} / \mathrm{dl}$. It is much lower than the values observed for rats administered via subcutaneous infusion.

Table 2 presents the AUCE values for RBC count and hemoglobin. AUCE for RBC increased by $28 \times 10^{6}$ cells/ $\mu \mathrm{l} \cdot$ day for SC injection and by $56,84,139 \times 10^{6} \mathrm{cells} / \mu \mathrm{l} \cdot$ day for administrations with rates of $0.25,0.5$ and $1 \mathrm{IU} / \mathrm{h}$. AUCE for hemoglobin showed a comparable pattern. It increased by $17 \mathrm{~g} / \mathrm{dl} \cdot$ day for subcutaneous injection, and by 71,110 and $198 \mathrm{~g} / \mathrm{dl} \cdot$ day for administrations with rates of $0.25,0.5$ and $1 \mathrm{IU} / \mathrm{h}$.

\section{Discussion}

The rHuEPO PK in rats is usually described by a two compartmental model with parallel first-order elimination and nonlinear Michaelis-Menten elimination. Absorption after SC injection is a process that consists of an initial, zeroorder, and a subsequent, first-order phase [10, 13]. Also, a target-mediated drug disposition approach was used to describe the pharmacokinetics of rHuEPO. In this case, binding of EPO to the receptor (EPO-R) and internalization of this complex was necessary to capture the nonlinear pharmacokinetics of rHuEPO observed for low doses [14]. For drugs exhibiting this type of disposition, an increase in apparent clearance with an increase in dose is observed $[15,16]$. In our study, apparent (due to unknown bioavailability) clearance was few-fold higher than observed in the literature. It could be explained by the difference in study design or different bioavailability after the long-term SC injection of the drug.

Pharmacokinetics of EPO after SC administration is usually described by flip-flop kinetics, implying the rate of elimination is faster than the rate of absorption. This phenomenon leads to a slow decline of the drug in plasma [10]. This phenomenon might explain the fact, that even at 22 days after implantation of the osmotic pumps rHuEPO was still present in rats' blood.

In a pharmacodynamic part of our work, the effect of continuous infusion of rHuEPO on RBC count and hemoglobin concentration was tested. We showed that administration of rHuEPO as a subcutaneous infusion is efficacious. In a study by Ait-Oudhia et al. [17], the peak number of RBC was $11.05 \cdot 10^{6}$ cells $/ \mu \mathrm{l}$ and the highest observed $\mathrm{Hb}$ concentration was $24.27 \mathrm{~g} / \mathrm{dl}$. It was observed after repeated three-times-per-week rHuEPO administration at a dose of $1350 \mathrm{IU} / \mathrm{kg}$ for 6 weeks. In our study, we found the highest responses $\left(12.2 \times 10^{6} \mathrm{cells} / \mu \mathrm{l}\right.$ and $21.3 \mathrm{~g} / \mathrm{dl}$, respectively) after infusion with a rate of $1 \mathrm{IU} / \mathrm{h}$ (total dose of $1333 \mathrm{IU} / \mathrm{kg})$, but even after the slowest infusion $(0.25 \mathrm{IU} / \mathrm{h}$, $333 \mathrm{IU} / \mathrm{kg}$ ), peak RBC count and $\mathrm{Hb}$ were $10.2 \times 10^{6}$ cells/ $\mu \mathrm{l}$ and $18.7 \mathrm{~g} / \mathrm{dl}$. This demonstrates, that a similar pharmacodynamic effect might be obtained with a lower amount of rHuEPO when it is delivered as a continuous infusion instead of repeated injection.

In our study design, we performed every procedure on both, treated and control groups, so a possible increase in hemoglobin and red blood cells due to the sampling should be detected in the control group. Rats in the control group had approximately constant hemoglobin content $(14.6 \pm 0.14 \mathrm{~g} / \mathrm{dl})$ during the whole experiment which is expected for 12-week old rats [10]. This indicates a lack of sampling effects on PD responses.

It has been observed that smaller doses of rHuEPO are required to maintain the same levels of hematocrit after subcutaneous injections than after intravenous injections $[8,9]$. Also for intravenous administration, about ten times higher peak concentrations are typically observed than after subcutaneous injection. This suggests that the hematological effect of rHuEPO is not driven by peak concentrations, but depends more on the duration of the drug concentration above the "critical concentration" or minimum effective concentration (MEC) [8]. The results presented in this paper confirm the thesis that hematological effect is largely dependent on how long the EPO remains in the circulation. Similar results to observed in this study might also be expected for pegylated forms of EPO and modern medicines, especially from the group of CERA (continuous erythropoietin receptor activator), due to the similar mechanism of action [20].

The stimulatory effects of erythropoietin are not solely dependent on the plasma concentration, but also dependent on the mechanism of EPO binding to its receptor. To date, it is unclear how long the ligand molecule is bound with the EPO-R. It is known that the amount of the erythropoietin receptor is relatively low on progenitor cells (about 200 receptors per cell), that these receptors have a different affinity for EPO, and that only about $20-30 \%$ of receptor occupancy is required to stimulate erythropoiesis [18, 19].

$\mathrm{rHuEPO}$ is used in the treatment of anemia, especially if it is associated with renal failure, AIDS, or during cancer chemotherapy [21, 22]. In the course of cancer, anemia affects about $90 \%$ of patients, of which $60 \%$ require a blood transfusion. Treatment with rHuEPO is an alternative to transfusion in cancer patients. Patients are usually receiving rHuEPO injection 3 or 4 times a week. In recent years, however, are growing doubts about the appropriateness of the use of erythropoietin in cancer patients in the view of reported decreased survival of cancer patients treated with 
EPO [22, 23]. It has been shown that in some cases administration of exogenous erythropoietin can stimulate the growth of tumors. This is probably related to the high doses of EPO and the presence of EPO-R receptors on the surface of certain cancer cells $[24,25]$. After binding the ligand, EPO-R can stimulate cell growth. EPO-R is also present on the surface of endothelial cells, which may suggest that there is a risk of stimulation of angiogenesis and tumor progression [22]. Based on the study it can be hypothesized that frequent administration of low doses of rHuEPO can be considered in the treatment of anemia in the course of neoplastic disease. It should lead to the same or higher efficacy and decreased risk of side effects (these driven by high EPO concentrations). Nevertheless, this phenomenon needs to be confirmed in appropriate clinical trials.

\section{Conclusion}

In this work, we have shown that the administration of rHuEPO by a continuous subcutaneous infusion is highly effective in rats. The same dose administered as an infusion leads to a pharmacological effect much greater than observed after single subcutaneous administration. It is possible to administer frequent low doses of $\mathrm{rHuEPO}$ and retain high efficacy of therapy. The dose leading to concentrations exceeding the minimum effective concentration results in an increase in hematological parameters, such as the level of red blood cells and hemoglobin. The use of lower doses might be beneficial due to decreased risk of side effects and reduction of treatment costs if confirmed in humans.

Acknowledgements This Project was supported by the Ministry of Science and Higher Education of the Republic of Poland, from the quality-promoting subsidy, under the Leading National Research Centre (KNOW) programme. We would like to thank Wojciech Krzyzanski for his helpful comments.

Author contributions Damian Szczesny: performing experiment, preparing manuscript. Katarzyna Mołoniewicz: performing experiment, preparing manuscript draft. Michał Markuszewski: final approval of manuscript. Paweł Wiczling: study concept, data analysis, final approval of manuscript.

\section{Compliance with ethical standards}

Conflict of interest Authors declares there is no conflict of interest.

Open Access This article is licensed under a Creative Commons Attribution 4.0 International License, which permits use, sharing, adaptation, distribution and reproduction in any medium or format, as long as you give appropriate credit to the original author(s) and the source, provide a link to the Creative Commons licence, and indicate if changes were made. The images or other third party material in this article are included in the article's Creative Commons licence, unless indicated otherwise in a credit line to the material. If material is not included in the article's Creative Commons licence and your intended use is not permitted by statutory regulation or exceeds the permitted use, you will need to obtain permission directly from the copyright holder. To view a copy of this licence, visit http://creativecommons.org/licenses/by/4.0/.

\section{References}

1. Jelkmann W. Molecular biology of erythropoietin. Intern Med. 2004;43(8):649-59.

2. Hodges VM, Rainey S, Lappin TR, Maxwell AP. Pathophysiology of anemia and erythrocytosis. Crit Rev Oncol Hematol. 2007;64(2):139-58.

3. Zhang Y, Andrews MC, Schyvens CG, McKenzie KUS, Whitworth JA. Adrenocorticotropic hormone, blood pressure, and serum erythropoietin concentrations in the rat. Am J Hypertens. 2004;17(5):457-61.

4. Fisher JW. Erythropoietin: physiology and pharmacology update. Exp Biol Med. 2003;228(1):1-14.

5. Chapel S, Veng-Pedersen P, Hohl RJ, Schmidt RL, McGuire EM, Widness JA. Changes in erythropoietin pharmacokinetics following busulfan-induced bone marrow ablation in sheep: evidence for bone marrow as a major erythropoietin elimination pathway. J Pharmacol Exp Ther. 2001;298(2):820-4.

6. Chapel SH, Veng-Pedersen P, Schmidt RL, Widness JA. Receptor-based model accounts for phlebotomy-induced changes in erythropoietin pharmacokinetics. Exp Hematol. 2001;29(4):425-31.

7. Jacob J, Jain K, John M, Kakkar N, Jaison V. Erythropoietin use and abuse. Indian J Endocrinol Metab. 2012;16(2):220-7.

8. Besarab A, Flaharty KK, Erslev AJ, McCrea JB, Vlasses PH, Medina F, et al. Clinical pharmacology and economics of recombinant human erythropoietin in end-stage renal disease: the case for subcutaneous administration. J Am Soc Nephrol. 1992;2(9):1405-16.

9. Yan X, Krzyzanski W. Quantitative assessment of minimal effective concentration of erythropoiesis-stimulating agents. CPT Pharmacometr Syst Pharmacol. 2013;2(8):62.

10. Woo S, Krzyzanski W, Jusko WJ. Pharmacokinetic and pharmacodynamic modeling of recombinant human erythropoietin after intravenous and subcutaneous administration in rats. J Pharmacol Exp Ther. 2006;319(3):1297-306.

11. Jelkmann W. Erythropoietin: structure, control of production, and function. Physiol Rev. 1992;72:449-89.

12. Krzyzanski W, Jusko WJ. Indirect pharmacodynamic models for responses with multicompartmental distribution or polyexponential disposition. J Pharmacokinet Pharmacodyn. 2001;28(1):57-78.

13. Ramakrishnan R, Cheung WK, Farrell F, Joffee L, Jusko WJ. Pharmacokinetic and pharmacodynamic modeling of recombinant human erythropoietin after intravenous and subcutaneous dose administration in cynomolgus monkeys. J Pharmacol Exp Ther. 2003;306(1):324-31.

14. Mager DE, Krzyzanski W. Quasi-equilibrium pharmacokinetic model for drugs exhibiting target-mediated drug disposition. Pharm Res. 2005;22(10):1589-96.

15. Woo S, Krzyzanski W, Jusko WJ. Target-mediated pharmacokinetic and pharmacodynamic model of recombinant human erythropoietin (rHuEPO). J Pharmacokinet Pharmacodyn. 2007;34(6):849-68.

16. Mager DE, Jusko WJ. General pharmacokinetic model for drugs exhibiting target-mediated drug disposition. J Pharmacokinet Pharmacodyn. 2001;28(6):507-32.

17. Ait-Oudhia S, Scherrmann JM, Krzyzanski W. Time-dependent clearance and hematological pharmacodynamics upon 
erythropoietin multiple dosing in rats. Biopharm Drug Dispos. 2010;31(5-6):298-315.

18. Macdougall I. Meeting the challenges of a new millennium: optimizing the use of recombinant human erythropoietin. Nephrol Dial Transpl. 1998;13(90002):23-7.

19. Macdougall IC. Optimizing the use of erythropoietic agentspharmacokinetic and pharmacodynamic considerations. Nephrol Dial Transplant. 2002;17(90005):66-70.

20. Duman N, Uyanik A, Unsal A, Sezer S, Camsari T, Cirit M, et al. Once-monthly continuous erythropoietin receptor activator (CERA) for haemoglobin maintenance in haemodialysis patients with chronic renal anaemia. Clin Kidney J. 2014;7:464-9.

21. Pérez-Ruixo JJ, Krzyzanski W, Hing J. Pharmacodynamic analysis of recombinant human erythropoietin effect on reticulocyte production rate and age distribution in healthy subjects. Clin Pharmacokinet. 2008;47(6):399-415.

22. Krzyzanski W, Jusko WJ, Wacholtz MC, Minton N, Cheung WK. Pharmacokinetic and pharmacodynamic modeling of recombinant human erythropoietin after multiple subcutaneous doses in healthy subjects. Eur J Pharm Sci. 2005;26(3-4):295-306.
23. Rizzo JD, Brouwers M, Hurley P, Seidenfeld J, Arcasoy MO, Spivak JL, et al. American society of clinical oncology/American society of hematology clinical practice guideline update on the use of epoetin and darbepoetin in adult patients with cancer. J Clin Oncol. 2010;28(33):4996-5010.

24. Udupa KB. Functional significance of erythropoietin receptor on tumor cells. World J Gastroenterol. 2006;12(46):7460-2.

25. Chan KK, Matchett KB, Coulter JA, Yuen HF, McCrudden CM, Zhang SD, et al. Erythropoietin drives breast cancer progression by activation of its receptor EPOR. Oncotarget. 2017;8(24):38251-63.

Publisher's Note Springer Nature remains neutral with regard to jurisdictional claims in published maps and institutional affiliations. 